\title{
New insights into IL-17/IL-23 signaling in ankylosing spondylitis (Review)
}

\author{
BEATRICE ANDREEA CHISĂLĂU ${ }^{1 *}$, LAURA-IOANA CRINGUS ${ }^{1 *}$, FLORENTIN ANANU VREJU $^{1}$, \\ CRISTINA DORINA PÂRVĂNESCU ${ }^{1}$, SINETA CRISTINA FIRULESCU ${ }^{1}$, ȘTEFAN CRISTIAN DINESCU ${ }^{1}$, \\ DANA ALEXANDRA CIOBANU ${ }^{1}$, ANDREI ADRIAN TICA ${ }^{2}$, RALUCA ELENA SANDU $^{3}$, ISABELA SILOȘI ${ }^{4}$, \\ MIHAIL VIRGIL BOLDEANU ${ }^{4,5}$, IOAN SABIN POENARIU ${ }^{4}$, ANCA MARILENA UNGUREANU ${ }^{6}$, \\ LIDIA BOLDEANU $^{6 *}$ and ANDREEA LILI BĂRBULESCU ${ }^{2}$
}

\author{
Departments of ${ }^{1}$ Rheumatology, ${ }^{2}$ Pharmacology, ${ }^{3}$ Biochemistry and ${ }^{4}$ Immunology, University of Medicine \\ and Pharmacy of Craiova, 200349 Craiova; ${ }^{5}$ Medico Science SRL Stem Cell Bank Unit, 200690 Craiova; \\ ${ }^{6}$ Department of Microbiology, University of Medicine and Pharmacy of Craiova, 200349 Craiova, Romania
}

Received June 2, 2020; Accepted July 2, 2020

DOI: $10.3892 / \mathrm{etm} .2020 .8981$

\begin{abstract}
Ankylosing spondylitis (AS) is a progressive common autoimmune inflammatory disease, part of the spondylarthritis group, characterized, besides clinical spinal and peripheral joint inflammation, by enthesitis and new bone formation, that can lead to severe functional impairment. Beyond intensive and continuous research on the pathogenic process extensively performed in recent years, their impact on therapeutic management remains open to future development. Better knowledge of AS pathogenesis have shown results progressively and studies are being performed to advance our current understanding of the disease. It is well known that tumor necrosis factor (TNF) exerts a central role, along with interleukin-17 (IL-17) and interleukin-23 (IL-23), demonstrated by several clinical studies. Similar to other rheumatic inflammatory conditions, SA is associated with an early process of systemic bone loss, both trabecular and cortical, consecutive osteopenia, osteoporosis, and high fracture risk. Current personalized therapeutic options benefit from new published data, to prevent future complications and to improve quality of life.
\end{abstract}

Correspondence to: Professor Mihail Virgil Boldeanu, Department of Immunology, University of Medicine and Pharmacy of Craiova, 2-4 Petru Rares Street, Dolj, 200349 Craiova, Romania

E-mail: boldeanumihailvirgil@yahoo.com

Professor Florentin Ananu Vreju, Department of Rheumatology, University of Medicine and Pharmacy of Craiova, 2-4 Petru Rares Street, Dolj, 200349 Craiova, Romania

E-mail: florin_vreju@yahoo.com

${ }^{*}$ Contributed equally

Key words: ankylosing spondylitis, interleukin-17, interleukin-23, IL-17/IL-23 pathway, bone loss

\section{Contents}

1. Introduction

2. Immunopathogenesis of ankylosing spondylitis

3. Effects of IL-23 and IL-17 on the bone

4. Conclusions

\section{Introduction}

Ankylosing spondylitis (AS) is a progressive common inflammatory disease, part of the spondylarthritis group ( $\mathrm{SpA})$, characterized, besides enthesitic inflammation, by new bone formation, that can be associated with both spinal and peripheral involvement. The burden of the disease is dependent on the degree of acute inflammation causing pain and stiffness and on new bone formation causing a reduction in spinal mobility and extra-articular features. Recent scientific publications have shown important advances in understanding new genetic associations and immune mediated processes, by studying genes that encode cytokine receptors, several transcription factors, or disturbances in antigen-presentation phenomenon (1-3).

Intestinal microbiota exerts a role in the pathogenic process, with no proven to little input, so far, on therapeutic management (4). Although important data have been published regarding genetic, cellular, and molecular pathways that regulate $\mathrm{SpA}$ pathogenesis, no new promising results came from new therapeutic options. Beyond intensive and continuous research performed in recent years, the input on therapeutic management remains opened to future development (1-4).

It is well known that tumor necrosis factor (TNF) exerts a central role, along with interleukin-17 (IL-17) and interleukin-23 (IL-23), demonstrated by several clinical studies. Furthermore, experimental research has proven that several autoimmune diseases, including AS, psoriatic arthritis (PsA), psoriasis, rheumatoid arthritis (RA), and Crohn disease (CD), can be triggered by activation of the IL-17/IL-23 pathway $(5,6)$.

AS also shows a strong hereditary background, related mostly, but not exclusively, to the presence of human leukocyte 
antigen-B27 (HLA-B27). Several theories have been proposed concerning the role of HLA-B27, the major one stating that changes in its amino acid sequences determines specificity for some peptides originated from certain bacterial proteins and cross-reactivity with peptides found in joints and enthesis, through induction of an immune-mediated cross-reactivity, mediated by $\mathrm{CD} 8^{+}$T-cells (7). Besides HLA-B27, other major histocompatibility complex (MHC) genes have been directly related to AS (i.e. HLA-B60, HLA-B61, HLA-B39) as well as non-MHC ones [endoplasmic reticulum aminopeptidase-1 and -2 (ERAP-1, ERAP-2), leucyl/cysteinyl aminopeptidase (LNPEP), IL-23 pathway genes, $\mathrm{CD} 8^{+} \mathrm{T}$-cell associated genes] (8-11).

This review includes a summary of the most recent data on AS pathogenesis from recent years, and their possible therapeutic impact.

\section{Immunopathogenesis of ankylosing spondylitis}

RA, psoriasis and PsA, as well as AS, are considered to be pathological processes regulated by the Thelper type 1 (Th1) subpopulation, and interferon- $\gamma$ (IFN- $\gamma$ ) and IL-2 were reported to be the leading mediators in the generation of the inflammatory cascade; recently, emerging data have underlined the role of the T helper type 17 (Th17-cells) subset and IL-17 in the pathological mechanisms leading to chronic arthritis such as PsA, AS, and even RA (12). The concept that states that AS is an IL-17 dependent disease has been clarified by genetic and immunological research (8-12).

IL-17. The Th17 cells, a subset of $\mathrm{CD} 4^{+} \mathrm{T}$-cells, described for the first time in 2005, exert immunity against extracellular bacterial and fungal infections, as the major physiological effect. Differentiation of Th17 cells is regulated by a combination of cytokines, such as IL-1 $\beta$, IL- 6 , transforming growth factor- $\beta$ (TGF- $\beta)$ and especially IL- 23 . Th17 cells release several cytokines, represented by IL-17-A, IL-17F, IL-22, IFN- $\gamma$, or granulocyte-macrophage colony-stimulating factor (GM-CSF) $(12,13)$. In AS, elevated levels of IL-17 have been found in serum, joint and synovial fluid. It has been recognized as a major pawn in disease pathogenesis, and the remarkable results obtained on animal models of SpA, sustained its therapeutic targeting. Consequently, it has been a continuous effort to identify whether IL-17 is the starting point or target of other cells $(14,15)$.

It has been reported that IL-17A producing cells, are frequently observed in AS patients. The decoy of epithelial cells, macrophages, neutrophils, or the release of IL- $1 \beta, \mathrm{TNF}-\alpha$, or other cytokines, supports its pathogenic involvement (16).

Despite its proinflammatory effect, IL-17A and IL-17F alone are not very powerful inflammatory cytokines; in fact, their potent inflammatory action is mostly related to the function of recruiting immune cells, and to the synergistic effect along with other pro-inflammatory cytokines such as TNF, IL-1 $\beta$, IFN- $\gamma$, GM-CSF and IL-22 (17).

There is increasing evidence that IL-17A blockade can be effective in patients with active SpA and knowledge regarding the mechanisms of IL-17/IL-23 pathway has increased with genetic, experimental models and functional data suggesting that it plays a crucial role in $\operatorname{SpA}(18)$.
Secukinumab, a fully human monoclonal antibody against IL-17A, is the first non-TNF- $\alpha$ inhibitor agent approved for AS, which opens up a therapeutic step of other cytokine targets beyond TNF (18). The benefits of secukinumab are generally seen regardless of whether patients were naive or not to TNF inhibitor therapy, and were persistent up to 5 years treatment; secukinumab was also associated with visible improvement of mobility and physical function, quality of life and work productivity in some of the trials (19).

Ixekizumab, a second emergent IL-17A blocker, has helped focus research towards IL-23/IL-17 axis in entheseal disease and the manner of IL-17A inhibition may be linked to innate and adaptive immune cells that are capable of IL-17A elaboration in these target tissues (19-21).

Ustekinumab, a human monoclonal antibody targeting the IL-12/23 p40 subunit, is effective in treating active psoriasis, $\mathrm{CD}$ and PsA, generating inhibition of radiographic progression, and improving axial symptoms in a subgroup of PsA patients with physician-reported spondylitis (22).

Clinical trials performed so far using new biologic compounds, targeting the IL-23/IL-17 axis, suggest important features that differentiate SpA and psoriasis from inflammatory bowel disease (IBD) and RA; these differences are obvious in therapeutic response and therefore require attention and further availability of new effective drugs that target different cytokines and inflammatory pathways. The observations made so far are creating new opportunities for the physician to impact disease activity and progression, for the benefit of these patients (13).

IL-23. The pathogenic role of IL-23, a heterodimeric cytokine, with some subunits, including IL-12B (IL-12p40), shared with IL-12 and IL-23A (IL-23p19) (23), was first supported by identifying IL-23R as involved in susceptibility to the disease. IL-23 might also be secreted by intestinal epithelium and produced by dendritic cells and macrophages (24). It has a major role in regulating, activating, and multiplying Th17 cells that express IL-17 and in inducing IL-22. The link between IL-23 and IL-17 has been proven on murine models, studying the differentiation of T-cells in Th17 cells $(24,25)$. The presence of IL-6 induces Th17 cell differentiation via TGF- $\beta$, while its absence induces differentiation of regulatory T-cells. The production of IL-17 was potentiated by IL-23 addition, but exclusively after their activation (26). Later experimental studies demonstrated the differentiation of non-pathogenic Th17 cells, under the action of IL- 6 and TGF- $\beta$, in case of IL-23 absence (27).

Furthermore, for mast cells, NK cells, $\gamma-\delta$ T-cells subpopulation ( $\gamma \delta \mathrm{T}$-cells; a population of $\mathrm{CD}^{+} \mathrm{T}$-cells) or innate lymphoid cells, IL-23 represents the main controller of IL-17 and IL-22 expression. Recent studies concluded that patients with AS or axial SpA present a significantly higher number of $\gamma \delta$ T-cells that express IL-23R and produce IL-17 $(27,28)$. Moreover, stimulation of $\gamma \delta$ T-cells with IL-23 induced a 6-fold increase for IL-17, expanded to 9-fold, after anti-CD3/CD28 addition (29).

A report, published in 2019 by Venken et al (30), described a new innate-like T-cells subset, ROR $\gamma t+$ TbetloPLZF-invariant NK T-cells (iNKT), that respond fast to IL-23 stimulation. The contribution of this cytokine to disease pathogeny is directly dependent on the presence of IL-23 producing cells. 
Regarding therapeutic approach, it has been suggested that IL-23 exerts a role only in initiating pathological process, both for AS or axial SpA, and not in perpetuating the damage in established disease. Administering IL-23 inhibitors did not provide satisfactory results, compared with IL-17. Studies with ustekinumab or risankizumab, that included subjects naïve to TNF inhibitors, did not show promising results $(31,32)$; moreover, ustekinumab was administered in patients with previous anti-TNF treatment or non-radiographic SpA, also without result (31).

Currently there are no data available on radiologic progression. Entheseal inflammation, a characteristic of SpA group, is potentiated by IL-23 using a population of $\mathrm{CD}^{+}{ }^{+} \mathrm{CD} 4^{-} \mathrm{CD} 8$ entheseal lymphocytes. Although in axial SpA ustekinumab showed no promising results, it is noteworthy that in patients with PsA it showed superior results, compared with placebo, in treatment of enthesitis $(33,34)$.

The lack of therapeutic response, compared with anti-IL-17 therapies, shows and underlines the importance of similarities and differences between IL-17 and IL-23, especially concerning cell differentiation, inflammation, bone destruction and formation (4). Related to cell differentiation, the first events are represented by IL-17 producing cell activation, via IL-1 and IL-6, subsequent to inflammation, followed by an increase of Th17 and $\gamma \delta$ T-cells; the presence of IL-23 can promote maturation into pathogenic Th17 cells $(26,35)$.

\section{Effects of IL-23 and IL-17 on the bone}

Similar to other rheumatic inflammatory conditions, SA is associated with an early process of systemic bone loss, both trabecular and cortical, consecutive osteopenia, osteoporosis, and high fracture risk. The focal new bone formation is a process that starts in well-established sites and it is related to future entheseal involvement $(1,6)$.

A wide view of structural damage in AS requires understanding how the cytokines released in an immune-mediated inflammatory disease act and regulate the bone loss or formation. The complete understanding of IL-23 action on osteoclasts and osteoclastogenesis is poorly understood, but it is clear that it promotes osteoclasts differentiation by inducing IL-17A production (36-38). It has been suggested that the process is induced in human cells by IL-23, in the absence of osteoblasts or the receptor activator of nuclear factor- $\kappa \beta$ ligand (RANKL) (36).

IL-23 promoting action on osteoclastogenesis is related to IL-23 stimulation inducing RANK expression on osteoclasts precursor and activation of DNAX protein 12 (DAP12) (38-42). There are also reports on sustained inhibitory effect on osteoclasts. Several in vitro and in vivo studies reported that IL-23 promotes GM-CSF production (inhibitor of osteoclast differentiation), limiting the resorption (39); osteoclast differentiation and bone resorption, enabled by IL-17 and RANKL expressed by Th17-cells, show that the effect on the bone can be a catabolic one. IL-23 has no effect on differentiation or proliferation of osteoblasts (43-46).

Evidence involving the effects of IL-17A on osteoblast differentiation and function are still not clear; it is suggested that IL-17A exerts a protective role for bone loss, indicating their positive effect on osteoblasts differentiation from mesenchymal stem cells (47-49). Inhibiting the cytokine with antibodies or soluble receptors determines a decrease of IL-6 and the carboxy-terminal collagen crosslinks (CTX) production and diminishes bone damage, an effect potentiated when associating TNF and IL-1 (44).

It is important to keep in mind that in inflammatory conditions, characterized by interaction and activation of mesenchymal cell-derived osteoblasts and osteoclasts, IL-17 and TNF produce a negative regulation of osteoblasts and bone damage, whereas in the absence of osteoblast-osteoclast interaction, determines new bone formation (50-54). The link between the two types of cells is the RANK-RANKL interaction $(36,55)$. Under the action of IL-17 and TNF, RANKL expression on mesenchymal cells increases, along with the RANK effect on osteoblasts $(6,48)$. Evidence shows that both IL-17 and IL-23 induce an imbalance in bone homeostasis, by a direct or indirect effect on osteoclasts, clinically visible as a systemic bone lost, contributing to bone erosions. The process of bone formation, in the cortical bone, common to AS and PsA, is enabled by the two cytokines via a local inflammatory environment that promotes bone response. Their action on bone is an open subject for future research to benefit therapeutic management $(3,6)$.

\section{Conclusions}

Improved knowledge of AS pathogenesis has shown results progressively and studies are being performed in order to advance our current understanding of the disease. Current and future personalized therapeutic options certainly benefit from new data, in order to prevent future complications and improve quality of life.

\section{Acknowledgements}

Not applicable.

\section{Funding}

No funding was received.

\section{Availability of data and materials}

Not applicable.

\section{Authors' contributions}

BAC, LIC, FAV, CDP, SCF, ȘCD, DAC, AAT, RES, IS, MVB, ISP, AMU, LB and ALB contributed equally to the acquisition, analysis and systematization of the data, and the writing and critical revision of the manuscript for important intellectual content. All authors read and approved the final version of the manuscript.

\section{Ethics approval and consent to participate}

Not applicable.

\section{Patients consent for publication}

Not applicable. 


\section{Competing interests}

The authors declare that they have no competing interests.

\section{References}

1. Ranganathan V, Gracey E, Brown MA, Inman RD and Haroon N Pathogenesis of ankylosing spondylitis - recent advances and future directions. Nat Rev Rheumatol 13: 359-367, 2017.

2. Barbulescu AL, Ciurea PL, Mitran C, Chisalau BA, Parvanescu CD, Firulescu SC, Balasoiu M, Boldeanu MV, Popoviciu H and Vreju FA: High frequency ultrasonography of the hand versus anti-RA33 evaluation in early rheumatoid arthritis - a pilot study. Med Ultrason 19: 166-171, 2017.

3. Bărbulescu AL, Sandu RE, Vreju AF, Ciurea PL, Criveanu C, Firulescu SC, Chisălău AB, Pârvănescu CD, Ciobanu DA, Radu M, et al: Neuroinflammation in systemic lupus erythematosus - a review. Rom J Morphol Embryol 60: 781-786, 2019.

4. Sieper J and Poddubnyy D: Pathogenesis of spondylarthritis: Relevance for treatment. Z Rheumatol 79: 5-12, 2020 (In German).

5. Yin J, Sternes PR, Wang M, Song J, Morrison M, Li T, Zhou L, $\mathrm{Wu} \mathrm{X}, \mathrm{He} \mathrm{F}$, Zhu J, et al: Shotgun metagenomics reveals an enrichment of potentially cross-reactive bacterial epitopes in ankylosing spondylitis patients, as well as the effects of TNFi therapy upon microbiome composition. Ann Rheum Dis 79 132-140, 2020.

6. Gravallese EM and Schett G: Effects of the IL-23-IL-17 pathway on bone in spondyloarthritis. Nat Rev Rheumatol 14: 631-640, 2018.

7. Pedersen SJ and Maksymowych WP: The pathogenesis of ankylosing spondylitis: An update. Curr Rheumatol Rep 21: 58, 2019

8. van Gaalen FA, Verduijn W, Roelen DL, Böhringer S, Huizinga TW, van der Heijde DM and Toes RE: Epistasis between two HLA antigens defines a subset of individuals at a very high risk for ankylosing spondylitis. Ann Rheum Dis 72: 974-978, 2013.

9. Reveille JD, Zhou X, Lee M, Weisman MH, Yi L, Gensler LS, Zou H, Ward MM, Ishimori ML, Learch TJ, et al: HLA class I and II alleles in susceptibility to ankylosing spondylitis. Ann Rheum Dis 78: 66-73, 2019.

10. Burton PR, Clayton DG, Cardon LR, Craddock N, Deloukas P, Duncanson A, Kwiatkowski DP, McCarthy MI, Ouwehand WH, Samani NJ, et al; Breast Cancer Susceptibility Collaboration (UK): Association scan of 14,500 nonsynonymous SNPs in four diseases identifies autoimmunity variants. Nat Genet 39: 1329-1337, 2007.

11. Evans DM, Spencer CC, Pointon JJ, Su Z, Harvey D, Kochan G, Oppermann U, Dilthey A, Pirinen M, Stone MA, et al; Spondyloarthritis Research Consortium of Canada (SPARCC); Australo-Anglo-American Spondyloarthritis Consortium (TASC); Wellcome Trust Case Control Consortium 2(WTCCC2): Interaction between ERAP1 and HLA-B27 in ankylosing spondylitis implicates peptide handling in the mechanism for HLA-B27 in disease susceptibility. Nat Genet 43: 761-767, 2011.

12. Cauli A, Piga M, Floris A and Mathieu A: Current perspective on the role of the interleukin-23/interleukin-17 axis in inflammation and disease (chronic arthritis and psoriasis). Immunotargets Ther 4: 185-190, 2015

13. Ruiz de Morales JMG, Puig L, Daudén E, Cañete JD, Pablos JL, Martín AO, Juanatey CG, Adán A, Montalbán X, Borruel N, et al: Critical role of interleukin (IL)-17 in inflammatory and immune disorders: An updated review of the evidence focusing in controversies. Autoimmun Rev 19: 102429, 2020.

14. Wendling D, Cedoz JP, Racadot E and Dumoulin G: Serum IL-17, BMP-7, and bone turnover markers in patients with ankylosing spondylitis. Joint Bone Spine 74: 304-305, 2007.

15. Mei Y, Pan F, Gao J, Ge R, Duan Z, Zeng Z, Liao F, Xia G, Wang S, $\mathrm{Xu} \mathrm{S}$, et al: Increased serum IL-17 and IL-23 in the patient with ankylosing spondylitis. Clin Rheumatol 30: 269-273, 2011.

16. Lau MC, Keith P, Costello ME, Bradbury LA, Hollis KA, Thomas R, Thomas GP, Brown MA and Kenna TJ: Genetic association of ankylosing spondylitis with TBX21 influences T-bet and pro-inflammatory cytokine expression in humans and SKG mice as a model of spondyloarthritis. Ann Rheum Dis 76: 261-269, 2017.

17. Jethwa $\mathrm{H}$ and Bowness P: The interleukin (IL)-23/IL-17 axis in ankylosing spondylitis: New advances and potentials for treatment. Clin Exp Immunol 183: 30-36, 2016.
18. Cheung PP: Anti-IL17A in axial spondyloarthritis-where are we at? Front Med (Lausanne) 4: 1, 2017.

19. Dubash S, Bridgewood C, McGonagle D and Marzo-Ortega H: The advent of IL-17A blockade in ankylosing spondylitis: Secukinumab, ixekizumab and beyond. Expert Rev Clin Immunol 15: 123-134, 2019.

20. van der Heijde D, Cheng-Chung Wei J, Dougados M, Mease P, Deodhar A, Maksymowych WP, van den Bosch F, Sieper J, Tomita T, Landewé R, et al; COAST-V study group: Ixekizumab, an interleukin-17A antagonist in the treatment of ankylosing spondylitis or radiographic axial spondyloarthritis in patients previously untreated with biological disease-modifying anti-rheumatic drugs (COAST-V): 16 week results of a phase 3 randomised, double-blind, active-controlled and placebo-controlled trial. Lancet 392: 2441-2451, 2018

21. Mease PJ, Smolen JS, Behrens F, Nash P, Liu Leage S, Li L, Tahir H, Gooderham M, Krishnan E, Liu-Seifert H, et al; SPIRIT $\mathrm{H} 2 \mathrm{H}$ study group: A head-to-head comparison of the efficacy and safety of ixekizumab and adalimumab in biological-naïve patients with active psoriatic arthritis: 24 -week results of a randomised, open-label, blinded-assessor trial. Ann Rheum Dis 79: 123-131, 2020.

22. Deodhar A, Gensler LS, Sieper J, Clark M, Calderon C, Wang Y, Zhou Y, Leu JH, Campbell K, Sweet K, et al: Three multicenter, randomized, double-blind, placebo-controlled studies evaluating the efficacy and safety of ustekinumab in axial spondyloarthritis. Arthritis Rheumatol 71: 258-270, 2019.

23. Deveci H, Turk AC, Ozmen ZC, Demir AK and Say Coskun SU: Biological and genetic evaluation of IL-23/IL-17 pathway in ankylosing spondylitis patients. Cent Eur J Immunol 44: 433-439, 2019.

24. Tan ZY, Bealgey KW, Fang Y, Gong YM and Bao S: Interleukin-23: Immunological roles and clinical implications. Int J Biochem Cell Biol 41: 733-735, 2009.

25. Benham H, Rehaume LM, Hasnain SZ, Velasco J, Baillet AC, Ruutu M, Kikly K, Wang R, Tseng HW, Thomas GP, et al: Interleukin-23 mediates the intestinal response to microbial $\beta-1,3$-glucan and the development of spondyloarthritis pathology in SKG mice. Arthritis Rheumatol 66: 1755-1767, 2014.

26. Bettelli E, Carrier Y, Gao W, Korn T, Strom TB, Oukka M, Weiner HL and Kuchroo VK: Reciprocal developmental pathways for the generation of pathogenic effector TH17 and regulatory T cells. Nature 441: 235-238, 2006.

27. Lee Y, Awasthi A, Yosef N, Quintana FJ, Xiao S, Peters A, Wu C, Kleinewietfeld M, Kunder S, Hafler DA, et al: Induction and molecular signature of pathogenic TH17 cells. Nat Immunol 13: 991-999, 2012.

28. Jansen DT, Hameetman M, van Bergen J, Huizinga TW, van der Heijde D, Toes RE and van Gaalen FA: IL-17-producing $\mathrm{CD} 4^{+} \mathrm{T}$ cells are increased in early, active axial spondyloarthritis including patients without imaging abnormalities. Rheumatology (Oxford) 54: 728-735, 2015

29. Kenna TJ, Davidson SI, Duan R, Bradbury LA, McFarlane J, Smith M, Weedon H, Street S, Thomas R, Thomas GP, et al: Enrichment of circulating interleukin-17-secreting interleukin-23 receptor-positive $\gamma / \delta \mathrm{T}$ cells in patients with active ankylosing spondylitis. Arthritis Rheum 64: 1420-1429, 2012.

30. Venken K, Jacques P, Mortier C, Labadia ME, Decruy T, Coudenys J, Hoyt K, Wayne AL, Hughes R, Turner M, et al: ROR $\gamma$ t inhibition selectively targets IL-17 producing iNKT and $\gamma \delta-T$ cells enriched in Spondyloarthritis patients. Nat Commun 10: 9, 2019.

31. Siloşi CA, Siloși I, Pădureanu V, Bogdan M, Mogoantă SȘ, Ciurea ME, Cojocaru M, Boldeanu L, Avrămescu CS, Boldeanu MV, et al: Sepsis and identification of reliable biomarkers for postoperative period prognosis. Rom J Morphol Embryol 59: 77-91, 2018.

32. Baeten D, Østergaard M, Wei JC, Sieper J, Järvinen P, Tam LS, Salvarani C, Kim TH, Solinger A, Datsenko Y, et al: Risankizumab, an IL-23 inhibitor, for ankylosing spondylitis: Results of a randomised, double-blind, placebo-controlled, proof-of-concept, dose-finding phase 2 study. Ann Rheum Dis 77: 1295-1302, 2018.

33. McInnes IB, Kavanaugh A, Gottlieb AB, Puig L, Rahman P, Ritchlin C, Brodmerkel C, Li S, Wang Y, Mendelsohn AM, et al; PSUMMIT 1 Study Group: Efficacy and safety of ustekinumab in patients with active psoriatic arthritis: 1 year results of the phase 3 , multicentre, double-blind, placebo-controlled PSUMMIT 1 trial. Lancet 382: 780-789, 2013. 
34. Araujo EG, Englbrecht M, Hoepken S, Finzel S, Kampylafka E Kleyer A, Bayat S, Schoenau V, Hueber A, Rech J, et al: Effects of ustekinumab versus tumor necrosis factor inhibition on enthesitis: Results from the enthesial clearance in psoriatic arthritis (ECLIPSA) study. Semin Arthritis Rheum 48: 632-637, 2019.

35. Albu CV, Padureanu V, Boldeanu MV, Bumbea AM, Enescu AS Albulescu DM, Silosi CA and Enescu A: Vascular neurocognitive disorders and the vascular risk factors. J Mind Med Sci 5 : $7-15,2018$

36. Yago T, Nanke Y, Kawamoto M, Furuya T, Kobashigawa $T$, Kamatani N and Kotake S: IL-23 induces human osteoclastogenesis via IL-17 in vitro, and anti-IL-23 antibody attenuates collagen-induced arthritis in rats. Arthritis Res Ther 9: R96, 2007.

37. Ju JH, Cho ML, Moon YM, Oh HJ, Park JS, Jhun JY, Min SY, Cho YG, Park KS, Yoon CH, et al: IL-23 induces receptor activator of NF-kappaB ligand expression on $\mathrm{CD}^{+} \mathrm{T}$ cells and promotes osteoclastogenesis in an autoimmune arthritis model. J Immunol 181: 1507-1518, 2008

38. Li X, Kim KW, Cho ML, Ju JH, Kang CM, Oh HJ, Min JK, Lee SH, Park SH and Kim HY: IL-23 induces receptor activator of NF-kappaB ligand expression in fibroblast-like synoviocytes via STAT3 and NF-kappaB signal pathways. Immunol Lett 127 $100-107,2010$

39. Chen L, Wei XQ, Evans B, Jiang W and Aeschlimann D: IL-23 promotes osteoclast formation by up-regulation of receptor activator of NF-kappaB (RANK) expression in myeloid precursor cells. Eur J Immunol 38: 2845-2854, 2008.

40. Caruntu C, Boda D, Dumitrascu G, Constantin C and Neagu M Proteomics focusing on immune markers in psoriatic arthritis. Biomarkers Med 9: 513-528, 2015.

41. Boda D, Negrei C, Nicolescu F and Badalau C: Assessment of some oxidative stress parameters in methotrexate treated psoriasis patients. Farmacia 62: 704-710, 2014.

42. Negrei C, Arsene AL, Toderescu CD, Boda D and Ilie M: Acitretin treatment may influence the cell membrane fluidity. Farmacia 60: 767-772, 2012.

43. Kamiya S, Nakamura C,Fukawa T, Ono K, Ohwaki T, Yoshimoto T and Wada S: Effects of IL-23 and IL-27 on osteoblasts and osteoclasts: Inhibitory effects on osteoclast differentiation. J Bone Miner Metab 25: 277-285, 2007.

44. Zhang JR, Pang DD, Tong Q, Liu X, Su DF and Dai SM: Different modulatory effects of IL-17, IL-22, and IL-23 on osteoblast differentiation. Mediators Inflamm 2017: 5950395, 2017.

45. Siloşi I, Boldeanu MV, Cojocaru M, Biciuşcă V, Pădureanu V, Bogdan M, Badea RG, Avramescu C, Petrescu IO, Petrescu F, et al: The relationship of cytokines IL-13 and IL-17 with wutoantibodies profile in early rheumatoid arthritis. J Immunol Res 2016 3109135, 2016
46. Silossi I, Boldeanu L, Biciuscă V, Bogdan M, Avramescu C, Taisescu C, Padureanu V, Boldeanu MV, Dricu A and Siloşi CA: Serum biomarkers for discrimination between hepatitis C-related arthropathy and early rheumatoid arthritis. Int J Mol Sci 18: E1304, 2017.

47. Huang H, Kim HJ, Chang EJ, Lee ZH, Hwang SJ, Kim HM, Lee Y and Kim HH: IL-17 stimulates the proliferation and differentiation of human mesenchymal stem cells: Implications for bone remodeling. Cell Death Differ 16: 1332-1343, 2009.

48. Osta B, Lavocat F, Eljaafari A and Miossec P: Effects of interleukin-17A on osteogenic differentiation of isolated human mesenchymal stem cells. Front Immunol 5: 425, 2014.

49. Silosi I, Cojocaru M, Foia L, Boldeanu MV, Petrescu F, Surlin P and Biciusca V: Significance of circulating and crevicular matrix metalloproteinase-9 in rheumatoid arthritis-chronic periodontitis association. J Immunol Res 2015: 218060, 2015.

50. Shaw AT, Maeda Y and Gravallese EM: IL-17A deficiency promotes periosteal bone formation in a model of inflammatory arthritis. Arthritis Res Ther 18: 104-113, 2016.

51. Kim YG, Park JW, Lee JM, Suh JY, Lee JK, Chang BS, Um HS, Kim JY and Lee Y: IL-17 inhibits osteoblast differentiation and bone regeneration in rat. Arch Oral Biol 59: 897-905, 2014.

52. Ono T, Okamoto K, Nakashima T, Nitta T, Hori S, Iwakura Y and Takayanagi H: IL-17-producing $\gamma \delta \mathrm{T}$ cells enhance bone regeneration. Nat Commun 7: 10928, 2016.

53. Nam D, Mau E, Wang Y, Wright D, Silkstone D, Whetstone H, Whyne C and Alman B: T-lymphocytes enable osteoblast maturation via IL-17F during the early phase of fracture repair. PLoS One 7: e40044, 2012.

54. Croes M, Öner FC, van Neerven D, Sabir E, Kruyt MC, Blokhuis TJ, Dhert WJA and Alblas J: Proinflammatory T cells and IL-17 stimulate osteoblast differentiation. Bone 84: 262-270, 2016.

55. Li JY, Yu M, Tyagi AM, Vaccaro C, Hsu E, Adams J, Bellido T, Weitzmann MN and Pacifici R: IL-17 receptor signaling in osteoblasts/osteocytes mediates PTH-induced bone loss and enhances osteocytic RANKL production. J Bone Miner Res 34: 349-360, 2019.

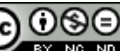

This work is licensed under a Creative Commons Attribution-NonCommercial-NoDerivatives 4.0 International (CC BY-NC-ND 4.0) License. 